\title{
Diversity and Board Effectiveness: A Case of India
}

\author{
R. K. Mishra \\ Institute of Public Enterprise, Hyderabad, India
}

\begin{abstract}
A number of research studies have dealt with the relationship between diversity and effectiveness of corporate boards. The present paper makes an attempt to provide an international perspective on diversity and effectiveness of corporate boards and examines such relationship in detail in the case of India. The paper presents the theory relating to diversity and board effectiveness with particular reference to women on boards. The position of diversity as related to the boards of National Stock Exchange (NSE) listed 511 companies and the 245 state-owned enterprises (SOEs) by the Government of India (GoI) is reflected in the paper. It then examines gender diversity specifically in the case of India and Singapore. Drawing from the evidence of diversity in the case of global companies, it offers the rationale for making boards global in composition and character. The paper highlights an interesting issue: whether the boards should have younger or veteran members? This follows a discussion on diversity of boards in terms of skills, age, and personalities. Finally, the paper makes suggestions for balance boards to enhance their effectiveness and brings out lessons for the corporate organizations to promote diversity of their boards.
\end{abstract}

Keywords: corporate governance, diversity, board effectiveness, board performance, board dynamics

\section{Introduction}

Board of directors is a group of persons elected or appointed by the shareholders to oversee the activities of a company. They are entrusted with the overall direction of the enterprise. Board's powers and duties are determined by corporate laws and bye laws of the organization. The company is owned by shareholders who elect the board of directors to act as trustees and protect their investment and interest. The board of directors in turn appoints the management team, who has operational responsibility of the organization. The management periodically reports to the board of directors on the functioning of the organization. The board is answerable to the shareholders.

The responsibility of the board is to "manage the organization" and the responsibility of managers, i.e., the CEO and his team, is to "manage the day-to-day activities or work of the organization" based on the guidelines, policies, and objectives laid down by the board. The objective of a company is long-term growth and sustainability. To this end, as representatives of the shareholders, the purpose of the board is to oversee the functioning of the organization and ensure that it continues to operate in the best interests of all stakeholders. The roles of a corporate board of directors are threefold: govern, direct, and supervise.

\section{Board Diversity and Board Performance}

The performance of corporate boards is dependent on directors effectively executing their roles and carrying out their responsibilities. Board dynamism has been a matter of great concern of late. The company's

R. K. Mishra, senior professor and director, Institute of Public Enterprise, OU Campus. Email: rkmishra@ipeindia.org. 
success and long-term survival is dependent on board decisions. These decisions impact shareholder, employees, customers, and all other stakeholders. Being a top performer in a highly complex and competitive environment is a major challenge. To achieve this, the board must comprehend the global environment, political and economic conditions in different countries, the industry's competitiveness and nuances, the market situation, financial and legal aspects, the latest technology, and it must have the ability to innovate and overcome challenges faced in turbulent times. Thus, the board must possess a wide range of knowledge, expertise skills, and perspectives. Such "completeness" is possible if the directors come from different backgrounds in terms of education, experience, country, and time periods. Thus, a significant factor influencing board performance is its composition: the type of directors who form the board. There is a growing consensus that diversity in board composition is necessary for effective board performance. Board diversity refers to the heterogeneous composition of the board in terms of gender, age, race, education, experience, nationality, lifestyle, culture, religion, and many other facets that make each of us unique as individuals. A well-performing board needs diversity of knowledge, skills, and perspectives. Argüden (2010) rightly commented that if everybody thinks in the same way, what is the need of a board? It may as well be a one-man show. Diversity for its own sake, however, is not an improvement in governance; what matters is the combination of complementary talent and experiences of members that enables boards to steer the company towards success and long-term stability. Great ideas come from differences. Differences can be created by diversity among the directors: demographic (gender, race) multi-disciplinary and cross-functional and roles (visionary, executor). Scholars and regulators have been advocating board diversity as a function of enhanced board effectiveness thereby improving corporate success. Heterogeneous boards with dissimilar opinions and approaches foster critical thinking and creative problem solving to effect better decision-making, allow active monitoring, and boost strategic direction, which are all the components essential for corporate success.

People from different backgrounds and with different life experiences are likely to approach similar problems in different ways. Evidence indicates that more diverse groups foster creativity and produce a greater range of perspectives and solutions to problems. That is, diverse groups are less likely to suffer from groupthink.

Companies are facing a talent crunch that goes right up to the top. Hiring women, minority, and people from different parts of the world can increase the talent pool of corporate boards. A diverse board facilitates policies and procedures that increase hiring and improves managing diverse employees.

Exposure of the organization to a wide variety of cultures, ideas, and views at every level, including the board, is needed to meet the demands of increasingly diverse employees, customers, and clients. A heterogeneous board will have a better understanding of the marketplace, increasing sales performance and hence profitability. Together with a diverse employee base, they will be able to customize products and services to the specific needs of diverse communities and penetrate new markets. "Homogeneity at the top of a company is believed to result in a narrow perspective while diverse top managers take a broader view. The result of diversity at the top is a better understanding of the complexities of the environment and more astute decisions" (Carter, Simkins, \& Simpson, 2003).

A primary responsibility of the board is to build external linkages and acquiring resources for the firm. By selecting directors with different characteristics, firms may gain access to different resources. For instance, directors with financial industry experience can help firms gain access to specific investors. Directors with political connections may help firms deal with regulators or win government procurement contracts (Hirschey, 
John, \& Makhija, 2009). Dissimilar group members may also contribute by acquiring information through a more diverse set of sources. For example, minority members' networks may give them access to unique sources of information.

Including women, minorities (ethnic, religious, etc.), and stakeholders' representatives (employees, suppliers, or minority shareholders) on the board helps firms enhance their reputation as responsible citizens. They are perceived as companies that protect the interests of all stakeholders, gaining respect in the eyes of media, government, and public at large.

Diversity, as argued, enhances the effectiveness of corporate leadership. While the rationales described above provide business justification for board diversity, there is also a social argument. Appointment of women, minorities, and people of different social levels (i.e., from lower castes in the Indian context) on boards will be an affirmative action for social and economic advancement.

\section{Board Diversity}

\section{Diversity: Limitations}

Creating a diverse board can be a challenge in terms of finding competent people. Diverse board, like any heterogeneous team, faces the problem of establishing mutual trust and understanding among members.

The literature provides sufficient evidence that diversity increases conflict between subgroups. A key problem that arises is poor communication among team members. Communicating effectively with teammates who do not share a common technical language or perspective is a challenge. Often, the question of status or superiority creates conflict. Effective management of diversity on boards is necessary to achieve the expected performance. Effort is required to increase group cohesiveness and improve flow of communication. Higher expenditure is required for these initiatives. Demographic diversity and functional diversity increase group conflict, reduce communication, and interfere with board functioning.

It may be found that few women, persons of lower social class (including caste in the Indian context), or minorities have the qualifications and experience needed for board-level appointment. Empirical research suggests that people who meet these requirements tend to hold multiple directorships. Thus, no one company gains a competitive edge by hiring them. Increased workload may also reduce their efficiency. As a result, finding suitable candidates may be difficult. It is important not to appoint directors just for the sake of diversity. There is no point appointing a woman who does not have the necessary skill or experience to participate in board deliberations. It is essential to have a balanced board with the right candidates who can positively contribute to the board.

\section{Diversity: Various Facets}

There are two broad categories of diversity: surface level and deep-level diversity. The surface level consists of observable and non-observable diversity. Deep-level diversity is concerned with personality diversity: perceptions, values, and personal characteristics. Attributes of directors that are easily determinable or visible fall under this category. Demographic factors such as race/ethnic background, nationality, gender, and age are examples of observable features. Gender diversity refers to the proportion of females to males. Men and women behave differently. Women are believed to be more intuitive in decision-making, have the ability to multitask, and are better at building relation. Men tend to be more task-focused and decisions are based on information and procedures. 
Age diversity indicates the mix of members of different ages. Younger people are perceived to be more flexible, have a better appreciation of new concepts and technologies, and are higher risk takers. They have the ability to grasp complex mathematical models and a deep understanding of the ability, reach, and limitations of Internet and online-based services. The board may, on the other hand, benefit from the wide experience of the senior members. Senior members often have strong networks and clout which the company can leverage.

Regional diversity implies that the board has members from different nationalities. Companies are now part of a global economy, having business activities in different parts of the world. Having a board that understands how different countries operate, their business environments, and their people is a necessity. Further, people from different countries have different lifestyles, cultures, and family backgrounds that help bring new perspectives and solutions to the table.

Diversity of tenure involves a balance between new and old directors. Having well-reputed directors on boards for a length of time improves corporate reputations. Directors who have been on the board for long periods will be likely to have a good understanding of the company, but this may run the risk of directors not keeping up with changes needed in the business and defending decisions that may not be appropriate in the present situation. It can also affect the independence of directors. A fresh pair of eyes always brings with it a new perspective. The literature mostly discusses racial and ethnic diversity in boards given the social structure of countries like the United States, Singapore, and Malaysia. It suggests that people of all racial and ethnic groups should be represented on the board. In the Indian context, the idea may be extended to include any social stratification such as religion or caste. Ethnicity refers to groups sharing a common language, cultural heritage, traditions, beliefs, and rituals. Religion involves a set of beliefs that are spiritual in nature and is specially considered with creation of a superhuman agency. In India, the concept of community refers to language and state of origin, another way in which groups in society exist: Bengalis, Gujaratis, Tamils, and so on. They share a common language and culture and are similar to ethnic groups. The caste system is also prevalent in India, originally as a classification according to one's function and occupation in society, but now considered hereditary.

Boards typically have directors from the same social background (community, religion, etc.) as the promoters in non-governmental organizations. Including socially diverse directors on board will help broaden the perspectives and experience of the whole team. Majority members may stigmatize the minorities, making it difficult for them to perform to their potential. An open and supportive environment should be created. It is important that the minorities be selected not just as tokens but rather on the basis of being competent people who are treated as peers so that they can effectively contribute to board activities.

Non-observable diversity relates to attributes that are less visible, such as educational qualifications, expertise, and experience. Multi-disciplinary boards are expected to be useful in decisions that are high in complexity and have many interdependent subtasks. Members with complementary education, knowledge, and skills can take a more comprehensive approach to problem solving. Research indicates that teams that are multidisciplinary tend to be more innovative. Members with varied experience, for example, in terms of functional, industry-specific, or specialized skills, look at problems differently and focus on different aspects of issues under consideration. This leads to creative problem solving and innovative decision-making. 
The personality of an individual is framed by his or her attitudes, attributes, social endowment, and skills. Each person has his or her own way of thinking and doing things. Some are introverts others extroverts. Some like to look at the big pictures; others are more comfortable with details and numbers. People with various personal traits will help board members carry out different responsibilities on the team and play a variety of roles in the decision-making process.

\section{Women on Boards}

Women in the United States make up $47.3 \%$ of the labor force and $51.4 \%$ of management, professional, and related positions, yet only $15.7 \%$ of board members are women (Catalyst, 2012). Australian women comprise $50.2 \%$ of the population, nearly $50 \%$ of the workforce, $56 \%$ of all higher education students, $55 \%$ of all university graduates, yet only $12.5 \%$ of directors of Australia's top 200 companies. Globally, $9.8 \%$ of directors are women, with only $58.3 \%$ of all companies having a female on board. Boards still recently were considered a "boys' club", with more than $40 \%$ of companies still having an all-male board. Across continents, the representation of women on boards is far from acceptable. Although in four European countries (Norway, Sweden, Finland, and France) women occupy more than 20\% of the seats, in other countries including the United States, UK, Germany, and New Zealand, women's representation on boards is only between $8 \%$ and $16 \%$. These countries are in the list of top 25 countries. The proportion of women in developed economies like Japan (0.9\%) and UAE (1.2\%) and the BRIC nations is minimal. Several countries such as Peru and Morocco have only all-male boards.

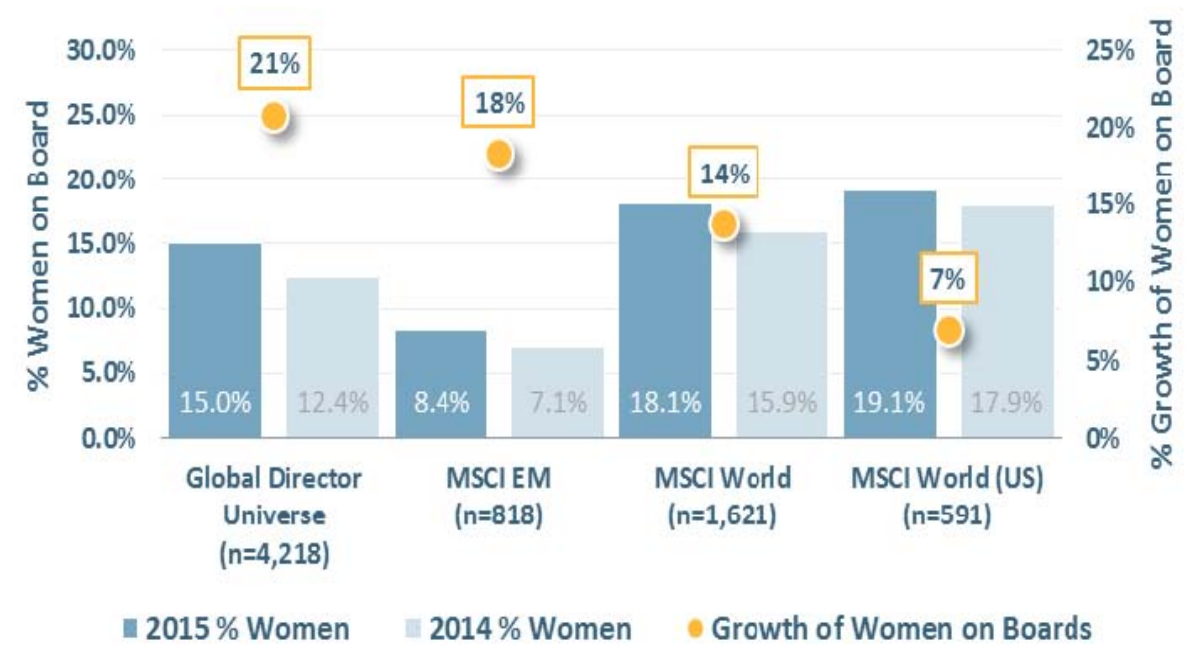

Figure 1. Global trend in women on boards, 2014-2015. Source: MSCI ESG Research (2015).

Figure 1 represents the MSCI World Index companies (MSCI ESG Research, 2015). As shown, women held $18.1 \%$ of all directorships (up from $15.9 \%$ last year) as of August 15, 2015, with women at MSCI USA companies holding $19.1 \%$ of directorships (up from $17.9 \%$ in 2014). Female directors comprised only $8.4 \%$ of boards at MSCI Emerging Markets Index companies (up from 7.1\% in 2014). Among the 4,218 companies covered in our global director reference universe, as of August 15, 2015, women held 15.0\% of all directorships, up from $12.4 \%$ last year and an increase of $4.8 \%$ since 2009. Norway (40.1\%), Sweden (33.7\%), and France (33.5\%) have the highest percentage of board seats filled by women. 


\section{Why So Few Women?}

The bias or prejudice against women that they cannot perform as well as men in top-level corporate jobs is probably the single most important reason for boards to still remaining male-dominated. Described as the "glass ceiling effect", it constitutes an invisible barrier that women face in the path to the top. Women often do not have mentors to guide them or role models to emulate. Men avoid mentoring women out of fear that their relationship will be considered personal, and there are simply not enough women at the top to mentor female board aspirants.

Men and women behave differently. Women are believed to be capable of multitasking, be more intuitive in decision-making, and better at building relation. Men, on the other hand, are assumed to be more task-focused and analytical in decision-making process. Women, as argued, are less likely to avoid controversial issues and ask the tough questions improving the quality of decision-making. Women, by being good listeners and facilitating a win-win approach, are able to reduce board conflict and improve board room dynamics.

Men, with their short-term and more performance-oriented approach, ensure that the company's goals are achieved. Male directors with an autocratic leadership style are able to exercise better control on management. The democratic leadership style of women encourages multiple views from different stakeholders. By their cooperative approach and long-term perspective, women directors are able to build positive and lasting relationships with management, customers, shareholders, and other stakeholders, thereby helping boards manage risk and making them more socially responsible.

Gender diversity (equal proportion of females to males) has a positive effect on boards. The McKinsey \& Company's (2008) report, Women Matter 2, found that women are more likely to apply leadership behaviours involving people development, expectations and rewards, and role model that have a positive effect on organizational performance. Men, on the other hand, adopt individualistic decision-making and control, and corrective action leadership behaviours.

Women are increasingly becoming a major driver of economy, both as contributor and customer; it is appropriate that they be a part of the team leading companies. In the United States, women are the economic powerhouse, influencing $95 \%$ of all products and services sold. Women currently drive $70 \%$ of purchasing decisions in Europe, even though they account for only $51 \%$ of population. Women now form $51 \%$ of the UK population and $46 \%$ of the economically active workforce. They are estimated to be responsible for about $70 \%$ of household purchasing decisions. Women are becoming influential even in traditionally male-dominated areas such as buying of cars. Thus, women are likely to better understand consumer behavior, the needs of different segments, and identifying opportunities for companies in satisfying these needs. Having women as board members can result in new products, larger customer base, and higher customer satisfaction, translating into bigger market share and more earnings. Boards with more women members act as a motivator to other women employees within the organization. Female directors are able to create a more women-friendly work environment in the company, reducing gender discrimination and incidence of sexual harassment.

Evidence shows that increased participation of women on boards enhances corporate performance. In 2004 and 2007, the US-based business, Catalyst (2012), reported that boards with the most female representatives outperformed those with least women representation in terms of return on equity (ROE), return on sales, and return on capital employed. The Reibey Institute (2011) of Australia in June 2011 found that over three- and five-year periods, ASX500 companies with women directors delivered significantly higher ROE than those companies without any women on their boards. 
Reputation and investor confidence may improve with the addition of women to a company's board. Institutional investors such as CalPERS (USA) and Amazone (Europe) are giving weight to gender diversity in their investment selection. Rating agencies such as Innovest and Vigeo are also adding gender diversity as a criterion to evaluate organizational excellence and corporate governance.

Companies are facing a huge talent crunch that goes right up to the board level. Broadening the talent pool by including women directors will help boards get skilled and competent members with diversity of perspectives and leadership styles who can significantly contribute to board performance.

\section{Gender Diversity - On the Move}

The ratio of women directors has been increasing slowly but steadily over the years. Globally, the percentage of women on boards has increased from $9.2 \%$ in 2009 to $9.6 \%$ in 2011 with $58 \%$ of the boards now having at least one female director. The increase in participation of women on boards has been more pronounced in Europe, from 5\% in 2001 to 8\% in 2004 to 9.7\% in 2008 to 12\% in 2011. There has been a steady increase in gender diversity, with the participation of women on board almost doubling in the last two decades. In countries such as the UK, the United States, Canada, Norway, Finland, Sweden, and Switzerland, $80 \%-90 \%$ of the boards have at least one female member. Asian countries such as India and Singapore have yet to cross the $50 \%$ mark.

Table 1

Change in Women Proportion on Boards

\begin{tabular}{lccc}
\hline Country & $2001(\%)$ & $2011(\%)$ & Change (\%) \\
\hline Finland & 4.63 & 24.50 & 429 \\
Norway & 8.45 & 35.60 & 321 \\
Sweden & 6.71 & 27.30 & 307 \\
Netherlands & 4.00 & 9.20 & 130 \\
UK & 6.40 & 14.20 & 122 \\
Denmark & 7.93 & 13.90 & 75 \\
Canada & 11.10 & 17.00 & 53 \\
New Zealand & 5.69 & 7.50 & 32 \\
USA & 12.40 & 16.10 & 30 \\
Italy & 4.20 & 3.70 & -12 \\
\hline
\end{tabular}

Scandinavian countries have become the best performers in terms of female representation on boards, with an increase of more than $300 \%$ over the last decade. The United States and Canada have also shown an increase by $30 \%$ and $53 \%$ over the last 10 years. Italy is probably the only country with a reverse trend, where the proportion of women on boards has actually fallen (see Table 1).

\section{More the Merrier}

It is not enough to appoint the "fairer sex" on board. They should not just be a symbolic representation of their gender. Qualified and competent women should be appointed who can actively contribute to board effectiveness. It is important to build an open and supportive environment where women members can comfortably participate and their views are not marginalized. While even a single female director can make significant contributions, it is important that she be heard and not be ignored or sidelined by the majority male members. Two female directors on a board would strengthen their position, and together they may have a better chance of being heard. Three or more women representatives on boards, popularly known as the "critical mass", 
will have a very strong impact on board functioning, as they will no longer represent a "women's view" but will become a "regular" board member, with a specific set of perspectives and skills.

In the global study of Fortune 200 companies in 2009, 23\% of boards had no women, 26\% had only one women director, $29 \%$ had two women directors, and $23 \%$ boards had three or more female directors. In Canada, $12 \%$ boards have four or more women directors, tripled the number since 2000. However in most countries, boards do not have four women members. The United States, Canada, and South Africa are the few countries where more than $15 \%$ boards have three or more women.

Governance Metrics International in its global study of 4,200 companies found that in 2009, 8.2\% companies had three or more women on their boards. In 2011, it had increased marginally to $8.4 \%$. In Canada, France, South Africa, Malaysia, and China, the number of boards with three or more female directors has increased but countries like South Korea and Indonesia still do not have boards with three female members. While more and more boards are having at least one female member, not many boards are actually increasing the number of women directors.

\section{Women in the Lead}

If the presence of women on boards is far from satisfactory, the number of women leading boards is even more disappointing. According to Governance Metrics International (2011), only 2.2\% of boards had female chairperson in 2011 (2.1\% in 2010 and 2.2\% in 2009). The Nordic Board Index 2010, covering 130 Scandinavian companies, reported only $3 \%$ of boards having a chairwoman. Norway, Canada, and Australia have been more proactive in appointed chairwomen, showing an increasing trend since 2009. In 2004, no Canadian board had a women chair; this has changed to 9\% currently. There are still no women chairs in large companies of Denmark, India, and Singapore.

Companies need to have a more open approach and facilitate opportunities for women to have board roles. Implementing work-life balance measures by allowing flexible working hours and accepting that women need career breaks could go a long way in encouraging women to aspire for senior-level positions. Organizations must strive for gender equality at all levels of the organization and ensure equal pay for men and women in similar roles. Insisting on equal male and female nominees when board recruitments are being done would give women a fairer chance. This is likely to necessitate actively searching for suitable women, thereby bringing forward women who are not so visible. Appropriate networking and mentoring facilities will help women prepare for top positions. If equal growth and promotion opportunities are facilitated over time, there will be a good number of women at senior positions that can be considered for board level positions.

Women need to become more visible by attending and speaking at professional gatherings and networking with peers from different industries. To increase the current female proportion on boards to the desired levels of $30 \%-40 \%$, companies are appointing more women on board (see Table 2). Over the same time period, the increase in female directors on the boards of S\&P 1500 companies mirrors the slow rise of female CEOs. Whereas there was an average of 1.2 female directors (12.5\% of the board) at S\&P 1500 companies in 2009, there is currently an average of only 1.5 female directors (15.8\% of the board). However, we do see some correlation between the presence of a female CEO and higher numbers of female directors. At female-led S\&P 1500 companies, there is currently an average of 2.8 female directors, or $28.6 \%$ of the board; the count includes the CEO. Male-led companies currently average 1.4 female directors, or $15.2 \%$ of the board. 
Table 2

Women CEOs Appointments on Boards

\begin{tabular}{lrrrrrr}
\hline & 2014 & 2013 & 2012 & 2011 & 2010 & 2009 \\
\hline Avg. WOB/female CEO & 2.8 & 2.5 & 2.6 & 2.5 & 2.4 & 2.5 \\
Avg. WOB (ex CEO)/female CEO & 1.8 & 1.5 & 1.6 & 1.5 & 1.4 & 1.5 \\
Avg. WOB/male CEO & 1.4 & 1.3 & 1.3 & 1.2 & 1.2 & 1.1 \\
WOB: Female CEO vs. male CEO & $29 \%$ & $15 \%$ & $23 \%$ & $25 \%$ & $17 \%$ & $36 \%$ \\
\hline
\end{tabular}

Note. Source: MSCI ESG Research.

\section{Towards a Broader Base}

Companies are facing a huge talent crunch that goes right up to the board level. Currently, there are not enough talented male directors who can help boards face the ongoing challenges. Men currently serving on boards are not in a position to take additional responsibility. Continuing reliance on existing directors is likely to dilute the quality of board members. Broadening the talent pool by including women directors will help boards get skilled and competent members with a diversity of perspectives and leadership styles who can significantly contribute to board performance.

\section{Gender Diversity: India and Singapore}

Gender diversity refers to the proportion of females to males in an organizational structure (school, company, courts, etc.) or workplace. The less the difference between the numbers of males and females, the greater is the diversity. Research on social and organizational behavior suggests that heterogeneous teams are more productive. As discussed in earlier chapters, diverse boards with directors with different traits and viewpoints can help in formulating suitable strategies, creative problem solving, improving productivity, and making boards more effective. There is a growing opinion that increasing the number of women on boards has a positive effect on performance, with several countries recommending quotas for women. In this chapter, we examine gender diversity in two important Asian countries: India and Singapore.

\section{Participation of Women}

Singapore with a female ratio of 5.6\% and India with $4.8 \%$ have the lowest proportion of women on boards. In fact, half of all boards did not have a female director. In India, only $3 \%$ boards have three women directors and in Singapore no board has three women directors.

\section{Passive Role of Women}

Where present, women directors appear to have a passive role. Few executive directors are women (2\%-3\%). Women members are mostly independent directors. In India, 33\% of women are non-executive directors of whom several are family owners or government/financial companies' nominees.

No board has a women chairperson. Only one board in each country has a female CEO. Not only is the number of women directors very small, but on the face of it they do not seem to be making a significant impact on board functioning.

\section{Women Directors Are Younger}

Boards consist of men from a wide range of ages, from 39 to 82 and 38 to 89 years old, with an average age of 59 and 63 in Singapore and India respectively. In comparison, women's age range is of 57 and 58 in Singapore and India; women directors are much younger than their male counterparts. Until just a few years 
ago, women were not likely to find themselves on boards or senior positions in companies, and this is probably the reason why there are fewer elderly women on boards.

\section{Women Directors Yet to Go Global}

Only $7 \%$ of the international directors in India are women. Of the 97 international directors in Singapore, none are women. This clearly shows that these two countries are not welcoming of female directors.

\section{Women - The Newcomers}

The average board tenure of male directors is five years more than female directors in Singapore and three years more in India. The gap between the maximum board tenure of male and female directors is very large. Further, 3\%-4\% more female directors have been a director for less than one year. This clearly indicates that boards are just beginning to include female directors. The statistics show that India has been more favorable than Singapore to the inclusion of women on boards.

\section{Qualification Myth}

Contrary to general belief, women are not more qualified than male board members. There are no female doctorates in the boards of either India or Singapore. In India, 6\% of women directors are undergraduates, a reflection of family-run businesses. In Singapore, however, there are more postgraduate/professional women than men as board members.

As expected, board members come mostly from management background, irrespective of gender ( $46 \%$ in the case of Singaporean female directors). No woman director has an engineering or science background, the second highest category in men. Law was one area where women dominated men. In India, the largest portion (29\%) of female directors is from the field of economics, something not found on Singapore boards. In Singapore, 23\% of women are financial professionals, $10 \%$ more than their male counterparts; in India, $6 \%$ of women are financial professionals, $11 \%$ less than male equivalents. Clearly, the education profile is different between the genders.

\section{Globalization}

In Singapore, about one-third of directors are from other countries. In comparison, only 8\% of US directors are non-US, up slightly from 6\% in 2005. In Australia, 33\% of directors of public companies were born there. In Europe, about $24 \%$ of directors are non-nationals, having grown gradually from $14 \%$ a decade ago. There are, however, great disparities among European countries. While Switzerland leads the way with $53 \%$, only $10 \%$ of board members in Spain are non-nationals. Even in 1998, 16\% of UK directors were foreigners, a figure that has risen steadily to $23 \%$ in 2001 , to $28 \%$ in 2004 , to the current level of $40 \%$. Of total Canadian directorships, international directors make up about one-fifth (22\%), resulting in an average of two international directors per board. In India, only $7 \%$ of directors are from other countries. This could be because several Indian directors have international education or experience. An additional deterrent could be that the cost of having an American or European director is very high, due to a disadvantageous exchange rate.

\section{Forced Globalization}

In India, only 7\% of directors are from other countries: $2 \%$ of directors on Indian boards are from Japan and about $1 \%$ each from the United States, UK, Germany, and Singapore. These members are mostly representatives of associated foreign companies which they have taken over or to which they have ties. Studies 
in Nordic countries suggest that foreign ownership is a major thrust for the internationalization of boards. Similarly, in a Russian study, it was found that $57 \%$ of independent directors in $80 \%$ of Russian companies that are listed internationally are foreign nationals, obviously to build confidence within the international community of investors. In contrast, only $22 \%$ of Russian companies planning for an initial public offering (IPO) had a few international directors.

\section{International Women Directors}

Only 7\% of international directors in India are women. Of the 97 international directors in Singapore, none are women. Asian countries seem to lag in comparison to Europe in appointing foreign women directors. In 2008, almost one-quarter of women directors in Europe were international members. In the Netherlands, $36 \%$ of female directors did not have Dutch nationality, compared to $24 \%$ of men. Currently in the UK, about $65 \%$ of male directors are British nationals, $12 \%$ are EU citizens, and another $11 \%$ are from the United States and Canada. Of the women directors, $55 \%$ are British, $9 \%$ are EU citizens, and as many as $29 \%$ of the female directors come from the United States and Canada. The rest of the women directors come from countries such as Kazakhstan, Saudi Arabia, Zambia, China, and South Africa. In 2004, 70\% of women directors were UK nationals, $19 \%$ were from the United States, and 7\% from Europe; the remainder of this group was from Hong Kong, Australia, and New Zealand. This shows that, over the years, not only has the proportion of international women directors in Britain increased; it has also become much more globally diverse.

Since 2007, the increase in women international directors has been much more prominent than that of men. One argument put forth for this is that the UK boards are killing two birds with one stone: fulfilling the need for both nationality and gender diversity at the same time. A similar trend is found in Canada, with $36 \%$ of all newly appointed women directors being from outside Canada, up from $20 \%$ in 2006 . What is surprising, though, is that all of the $36 \%$ were US residents.

\section{Skill and Talent Matters to Singapore}

Only $45 \%$ of executive directors in Singapore are local, $36 \%$ are from other Asian countries, and another $15 \%$ are from European countries. Of all the Singaporeans on boards, $12 \%$ are executives, $20 \%$ are non-executives, and as many as $68 \%$ are independent directors. Thirty-five percent of Asian directors (other than Singaporean) were executive directors. This suggests that in the selection of executive directors, talent and ability to run the company are more important than the country they belong to. Companies are besieged with a huge talent gap that extends all the way up to the boardroom. Companies need talented, experienced, and able directors who have the skills to meet new challenges and add value to the organization. The question arises whether companies widen their search to include international directors to fill this need.

\section{Value-Adding Boards}

A board may prove to be one of the following: a board that creates negative value (deteriorates the company from its earlier position); a board that creates no value (ensures compliance and maintains the status quo); or a board that creates value (through vision and strategic guidance). Every board desires and strives to be a "value creator". They all want to live up to the expectations placed on them. They want to create great companies, companies that are not just "tracked by history" but that "create history". A far-sighted board with a strong character and the ability to do things differently can do that. This calls for a board with a vibrant 
personality, a 360-degree view capable of taking complex decisions in trying situations and making sure that those decisions are implemented, yet quickly changing these very decisions if circumstances change. As discussed earlier, such a board needs to be made of members who are heterogeneous in terms of personality gender, age, race, nationality, education, and experience. Although diversity is logical and intuitively sound for enhancing board performance, a view that has become widely accepted, empirical findings have not been that convincing.

\section{Diversity of SOEs Boards in India}

The diversity dimension of SOEs boards in India has been discussed with reference to age, educational background, work experience, and internationalization. Only the listed SOEs on the National Stock Exchange (NSE) have been considered for the study and compared with their counterparts in the private sector listed on the NSE. As Table 3 shows, of the total number of 42 listed SOEs in 2014, there were only 22 companies having 26 women directors on their boards. It may be noted that during 2012-13, 21 listed companies had a total number of 31 women directors on their boards. For the non-SOEs listed on the NSE, this number increased from 533 in 2013 to 593 in 2014. The listed SOEs belonged to minerals, energy, financial services, and steel sectors.

Table 3

Diversity of Listed SOE Boards in India

\begin{tabular}{lcc}
\hline Particulars & 2013 & 2014 \\
\hline Total no. of listed SOEs & 42 & 42 \\
SOEs having women board members & 21 & 22 \\
Total no. of women board members & 31 & 26 \\
Doctorates & 8 & 5 \\
Graduates & 9 & 9 \\
Postgraduates & 14 & 12 \\
No. of women directors in listed non-SOEs & 533 & 593 \\
\hline
\end{tabular}

The Section 149 of the Indian Companies Act 2013 deals with the provisions relating to appointment of directors and matters such as the minimum and maximum numbers of directors, type/class of directors to be appointed. As per this section:

(1) Every listed company shall appoint at least one woman director within one year from the commencement of the second provision to Section 149(1);

(2) Every other public company: having paid up capital of 100 crore or more or a turnover of 300 crore or more have to compulsorily appoint within three years from the commencement of second proviso to Section 149(1) of the Act.

A time limit of one year is provided to fall in line with the new requirement. A search for right kind of women directors has to be made and it is certainly a time-consuming exercise. As per Section 152(5), every person including a woman director who has been appointed to hold the office of a director shall on or before the appointment furnish to the company consent in writing to act as such in Form No. 11.2 and comply with the requirements for filing of consent on Ministry of Corporate Affairs (MCA) portal. Woman director proposed to be appointed has to obtain Director Identification Number and shall give a declaration that she is not disqualified to be appointed as a director. 
The data showing the meager presence of women directors on the boards of the listed SOEs very clearly point out that there has been little regard paid by the SOEs to the provisions of the Indian Companies Act 2013. About two-thirds of the women directors on the SOEs boards had doctorate or postgraduate qualifications. They represented occupations such as civil services, consultancy, accounting, law, and academia. Only one SOE had a women member as the chairman and managing director.

\section{Building the Balanced Boards}

The way the board performs is influenced by the type of directors it has. The board should be formed of individuals who are highly talented, dynamic, and geared up to face today's challenging and ever-changing business environment. For the complex role of boards, a balanced team of heterogeneous directors is required. Diversity "just for the heck of it" will not be beneficial. A SWOT analysis of the board will determine its competency to meet current business challenges and identify areas which need to be strengthened. At the same time, some board members may have outlived their utilities, and it may be advisable to replace them.

Ultimately, what is important is the unique contribution each potential broad member will bring to the table. The focus must be on what is to be achieved by board diversity. The aim must be to have a broad talent base. There is no ideal mix of directors: It depends on the needs of the company and its business. It is important to understand the talents and skills that will be needed in the future and plan accordingly. Just like employee management, board talent must be strategically managed to build a competent board with diverse perspectives and skills. Not just CEO succession planning but a dynamic board succession planning process must be put in place, whereby through an aggressive recruitment process top-quality members are selected based on the current and future needs. To enhance board performance and create value that diverse boards can generate, members need to recognize the diversities, appreciate and respect the diversities, learn to work as a team, irrespective of diversity and leverage the diversity.

\section{Conclusion}

The performance of corporate boards has always been a matter of great concern. Boards need to create long-term shareholder value while protecting the interest of all other stakeholders. One significant factor influencing board performance is its composition, that is, the types of directors who form the board. There is a growing concern that diversity in board composition is necessary for effective board performance. To conclude, board diversity provides key to the board effectiveness.

\section{References}

Argüden, Y. (2010). Diversity at the head table: Bringing complementary skills and experiences to the board. Private Sector Opinion No. 19. A Global Corporate Governance Forum Publication.

Carter, D. A., Simkins, B. J., \& Simpson, W. G. (2003). Corporate governance, board diversity, and firm value. Financial Review, 38(1), 33-53.

Catalyst. (2012). Statistical overview of women in the workplace.

Governance Metrics International. (2011). Women on boards. February 2011.

Hirschey, M., John, K., \& Makhija, A. K. (2009). Corporate governance and firm performance (p. 117). Emerald Group Publishing.

McKinsey \& Company. (2008). Women matter 2: Female leadership, a competitive edge for the future.

MSCI ESG Research. (2015). Women on boards: Global trends in gender diversity on corporate boards. November 2015.

Reibey Institute. (2011). ASX 500 - Women leaders - Women on boards. Research Notes. 